\title{
International Committee on Systematic Bacteriology Subcommittee on the Taxonomy of Vibrionaceae
}

\author{
Minutes of the Meetings, 8 and 11 September 1986, Manchester, England
}

\section{Session 1. Closed meeting.}

Minute 1. Call to order. The closed meeting was held at 8:00 p.m. on 8 September 1986 in Room 2.4 of the Roscoe Building, University of Manchester. The meeting was called to order by the Secretary, J. J. Farmer, at the request of the Chairman, R. Sakazaki, who sent his regrets for a conflict with another subcommittee meeting, which he had to chair. John V. Lee volunteered to assist in recording the proceedings of the meeting.

Minute 2. Record of attendance. The members present were R. R. Colwell, J. J. Farmer (Secretary), John V. Lee, and Ralph H. W. Schubert. Yoshimasa Kosako was introduced and participated as a designated voting alternate for R. Sakazaki during his absence.

Minute 3. Agenda. The written agenda previously mailed to members was presented, several items were added, and the agenda was approved. The minutes of the previous meetings which were held on 4 and 11 August 1982 in Boston, Mass., had been approved by mail and have been published (Int. J. Syst. Bacteriol. 34:251-252, 1984). A copy was given to each member.

Minute 4. Changes in membership and officers. John V. Lee was introduced as a new member of the subcommittee. Paul Baumann, Suhas Sanyal, and M. Veron retired from the subcommittee in 1985 or 1986. These resignations were accepted with regret, and letters of appreciation for service to the subcommittee have been sent. R. Sakazaki was elected for a third term as Chairman, and J. J. Farmer was elected for a second term as Secretary. There was a long discussion on the need for new members and on the size of the subcommittee and the scope of its activities. About a dozen prospective members were discussed. Don J. Brenner, Patricia Desmarchelier, M. S. Hendrie, Barry Holmes, Anwarul Huq, Michael T. Kelly, Yoshimasa Kosako, and G. Balakrish Nair were elected as new members. (Subsequently, all eight accepted the invitation.)

Minute 5. Current membership. The current voting membership of the subcommittee is as follows: Don J. Brenner, Atlanta, Ga.; R. R. Colwell, College Park, Md.; Patricia Desmarchelier, Sydney, Australia; J. J. Farmer (Secretary), Atlanta, Ga.; M. S. Hendrie, Aberdeen, Scotland; Barry Holmes, London, England; Anwarul Huq, Dhaka, Bangladesh; Michael T. Kelly, Vancouver, Canada; Yoshimasa Kosako, Saitama, Japan; John V. Lee, Salisbury, Wiltshire, England; G. Balakrish Nair, Calcutta, India; R. Sakazaki (Chairman), Tokyo, Japan; and Ralph W. H. Schubert, Frankfurt/Main, Federal Republic of Germany.

Minute 6. Working groups. In 1986 each subcommittee member was sent a mailing in which the Chairman proposed working groups in various areas to expedite the accomplishment of the responsibilities of the subcommittee. A questionnaire was included for subcommittee members to indicate their interest in chairing and/or participating in the working groups. There was a discussion on the make-up and function of the working groups, with a consensus that they would prove useful. The remainder of the meeting was devoted to the various working groups.
Minute 7. Working Group on Vibrio cholerae Serotyping. This group has been formed and is beginning to function. Originally, it was to be chaired by Terrance Donovan (Vibrio Laboratory, Maidstone Public Health Laboratory, Maidstone, Kent, England). However, a reorganization of the Public Health Laboratory Service of England resulted in the transfer of all Vibrio work to Colindale and the need to designate a new chairman. Toshio Shimada (Department of Bacteriology, National Institute of Health, Tokyo, Japan) will chair this working group. Additional scientists who have an interest in $V$. cholerae serotyping have been or will be invited to join the working group.

Minute 8. Working Group on Minimal Standards. The Chairman had previously asked J. J. Farmer to chair the Working Group on Minimal Standards. In 1986 a questionnaire was sent to subcommittee members asking them to give their opinions on more than 100 phenotypic tests and several dozen other criteria. Members were asked to rate each criterion as minimal, desirable but not minimal, optional, or unnecessary. A summary of the opinions of the members was presented with the conclusion that there were very diverse opinions on what should be a minimal characteristic. Several members expressed strong opinions that techniques which measure evolutionary distance must be included in a paper describing new genera and species. Others felt that such experiments are desirable but are too specialized to be minimal. It was mentioned that the Enterobacteriaceae Subcommittee had completed a draft of its document on minimal standards and that this might be helpful. The Working Group on Minimal Standards will be formed after the new members have indicated their interest. A document on minimal standards should be completed before the next International Congress. Although it will be difficult to arrive at a consensus for this document, the subcommittee is specially charged with this duty under the International Code of Nomenclature of Bacteria.

The meeting was adjourned at 10:15 p.m.

\section{Session 2. Open meeting.}

Minute 9. Call to order. The open meeting was held at 8:00 p.m. on 11 September 1986 in Room 2.4 of the Roscoe Building, University of Manchester. The meeting was called to order by the Chairman, R. Sakazaki, who asked the Secretary to assist in conducting the meeting.

Minute 10. Record of attendance. The members present were R. R. Colwell, R. Sakazaki, J. J. Farmer, John V. Lee, and Ralph H. W. Schubert. In addition, there were nine guests (including three who had been elected to membership at the closed meeting).

Minute 11. Summary of the closed meeting. J. J. Farmer read a summary of the closed meeting.

Minute 12. Working Group on Plesiomonas Serotyping. R. Sakazaki reported the need for the Working Group on Plesiomonas Serotyping because there are two published antigenic schemata for Plesiomonas. Members of the working group include Toshio Shimada (National Institute of Health, Tokyo, Japan), Eva Aldova (Institute of Hygiene 
and Epidemiology, Prague, Czechoslovakia), and Roger Gross (Central Public Health Laboratory, Colindale, England).

Minute 13. Concept and definition of the family Vibrionaceae and its relatives. In 1986 there was a proposal to remove the genus Aeromonas from the family Vibrionaceae and establish a new family Aeromonadaceae, with the single genus Aeromonas (R. R. Colwell, M. T. Macdonell, and J. DeLey, Int. J. Syst. Bacteriol. 36:473-477, 1986). R. R. Colwell summarized the data that led to their conclusion that "Aeromonas possess an evolutionary history sufficiently different from that of Vibrionaceae to warrant removal from this family." She also mentioned that Plesiomonas also "sits by itself," but was not proposed as a new family. There was a lively discussion on the relative merits of various techniques, such as $16 \mathrm{~S}$ ribosomal ribonucleic acid catalogs, $5 \mathrm{~S}$ ribosomal ribonucleic acid sequences, ribonucleic acid-deoxyribonucleic acid (DNA) hybridization, DNA-DNA hybridization, protein structure relatedness, and phenotype. These techniques sometimes give different answers concerning the best way to classify organisms. It was pointed out that classification of plants and animals above the level of genus is usually a controversial topic, and these higher classifications tend to change with time.

Minute 14. Classification of the new genus Allomonas. In 1984 Kalina et al. proposed Allomonas as a genus in the family Vibrionaceae (G. P. Kalina, A. S. Antonov, T. P. Turova, and T. J. Grafova, Int. J. Syst. Bacteriol. 34: $150-154,1984)$. For some time there were no strains available for study in the West, but the American Type Culture Collection obtained the type strain from the National Collection of Type Cultures of the USSR (BKM; All-Union Culture Collection, Moscow). The strain is cataloged as strain ATCC 35843 (= BKM B1485). Based on study of this type strain, several subcommittee members commented that they felt that Allomonas enterica is a (junior) synonym of Vibrio fluvialis. The two organisms are essentially identical in phenotype and are highly related as determined by DNADNA hybridization.

Minute 15. Classification of the new genus Halomonas. In 1980 Halomonas was proposed as a new genus of extremely salt-tolerant bacteria (R. H. Vreeland, C. D. Litchfield, E. L. Martin, and E. Elliot, Int. J. Syst. Bacteriol. 30: 485-495, 1980). Halomonas elongata was the only species in the genus, which was classified by the authors in the family Vibrionaceae. Several subcommittee members commented that they had studied strains of Halomonas elongata and felt that these organisms are nonfermentative, gram-negative bacteria, which would exclude them from the family Vibrionaceae. These comments agree with the exclusion of Halomonas from the family Vibrionaceae in Bergey's Manual of Systematic Bacteriology, vol. 1; the genus Halomonas was included with other nonfermentative organisms in Section 4, Gram-Negative Aerobic Rods and Cocci.

Minute 16. Nomenclatural status of Vibrio alginolyticus subsp. iophagus. In 1983 Emod et al. (I. Emod, P. Soubigou, N. T. Tong, B. Keil, and C. Richard, Int. J. Syst. Bacteriol. 33:451-459, 1983) studied strain I.029 of Achromobacter iophagus, which was described in 1973 by Welton and Woods (R. L. Welton and D. R. Woods, J. Gen. Microbiol. 75:191-196, 1973), and found that it is very closely related to Vibrio alginolyticus. In the last paragraph Emod et al. stated:

"On the basis of the results reported here, it is apparent that strain CIP 82.01 of $V$. alginolyticus and strain I.029, which was originally designated "A. iophagus," are closely related organisms and belong to the same species ( $V$. alginolyticus). Nevertheless, differences in the collagenases produced by these two strains indicate that the organisms are not identical. Therefore we suggest the name Vibrio alginolyticus chemovar iophagus for strain I.029 and the name iophagus collagenase for the corresponding enzyme."

The International Code of Nomenclature of Bacteria (see p. 125-127) states that subdivisions below the level of subspecies (infrasubspecific subdivisions) have no standing in nomenclature and "are not covered by the Rules of this Code." However, the name Vibrio alginolyticus subsp. iophagus appears in the "Index of the Bacterial and Yeast Nomenclatural Changes Published in the International Journal of Systematic Bacteriology since the 1980 Approved Lists of Bacterial Names (1 January 1980 to 1 January 1985)" (W. E. C. Moore, E. P. Cato, and L. V. H. Moore, Int. J. Syst. Bacteriol. 35:382-407, 1985). The introduction of this list states:

"The following list includes the official nomenclature of bacteria and yeasts recognized by the International Committee on Systematic Bacteriology as published or validated in the International Journal of Systematic Bacteriology (IJSB) according to the International Code of Nomenclature of Bacteria (ICNB), Rule 27. References to nomenclature established by the 1980 Approved Lists of Bacterial Names are designated by (AL). Except where noted, all references pertain to IJSB. References to original referred articles published in IJSB are marked with an asterisk $\left(^{*}\right)$. References to names that appear only on validation lists give only the year, volume, and page number without special designations.

The validity of species is not guaranteed by inclusion in these lists. However, the priority of the name is established by the date and page of publication in IJSB either as an original article or by mention in the validation lists (ICNB Rule 27).'

These statements indicate that Vibrio alginolyticus subsp. iophagus has standing in nomenclature. However, a letter was written by the Secretary of the Vibrionaceae Subcommittee to I. Emod and colleagues asking them whether they had intended to propose a new subspecies. The reply was read to the subcommittee; this reply indicated that the authors clearly did not propose a new subspecies name, but were merely indicating a "chemovar." Rule $28 \mathrm{~b}$ (p. 28) of the International Code of Nomenclature of Bacteria states:

"A name or epithet is not validly published which is: (1)

Not accepted at the time of publication by the author who published it."

The members of the subcommittee were of the unanimous opinion that Vibrio alginolyticus subsp. iophagus is an illegitimate name because of Rule $28 \mathrm{~b}$. This issue will be referred to the editor of the International Journal of Systematic Bacteriology or to the Judicial Commission with a request that the name be deleted from all lists that indicate that it has standing in nomenclature.

Minute 17. Priority of Aeromonas punctata over Aeromonas caviae. In Bergey's Manual of Determinative Bacteriology, 8th ed., Aeromonas hydrophila, Aeromonas punctata subsp. punctata (type strain NCMB 74 [= ATCC 23309]), Aeromonas punctata subsp. caviae (type strain ATCC 15468), and Aeromonas salmonicida are listed as the species of the genus Aeromonas. All of these organisms were included on the 1980 Approved Lists of Bacterial Names, but a mistake was made in the type strain for Aeromonas 
punctata subsp. punctata. The type strain was incorrectly listed as strain ATCC 15468 rather than strain ATCC 23309 (= NCMB 74). Thus, on the 1980 Approved Lists, strain ATCC 15468 was listed as the type strain for the following three organisms: Aeromonas punctata, Aeromonas punctata subsp. punctata, and Aeromonas punctata subsp. caviae. Organisms that share the same type strain are normally treated as objective synonyms.

In 1984, Popoff revived the name Aeromonas caviae and considered it to be a valid species in the genus Aeromonas along with Aeromonas hydrophila, Aeromonas sobria, and Aeromonas salmonicida (M. Popoff, p. 545-548, in N. R. Krieg and J. G. Holt, ed., Bergey's Manual of Systematic
Bacteriology, vol. 1. The William and Wilkins Co., Baltimore). The problem with this classification is that Aeromonas caviae is an illegitimate name because it is a junior objective synonym of Aeromonas punctata. This is because the International Code of Nomenclature of Bacteria has no rules to consider errors made in the designation of type strains on the 1980 Approved Lists. There was considerable discussion on this nomenclatural problem and options to resolve it. It was concluded that it would require an Opinion from the Judicial Commission.

The meeting was adjourned at 9:50 p.m.

J. J. Farmer III, Secretary 